\title{
Biography and Scholarship. In Memory of Guenther Roth
}

\author{
Luciana Villas Bôas
}

About a year ago, I booked a flight from Rio de Janeiro to NYC to pay my last visit to Guenther Roth. A few weeks earlier, a friend had told me that his illness had reached a terminal phase. I was fortunate to find him in good shape, ready to take me for lunch in his favorite neighborhood restaurant, and to the latest exhibition on the history of jewelry in the Metropolitan Museum. As he grew feebler towards the end of my stay, instead of taking me to an exhibition on the Hudson River at New York Historical Society, he invited me for tea and cake at his place on Riverside Drive. These were the rituals we followed for over twenty-three years, from 1996 through 2019, hence from the time I was a young graduate student at Columbia University until I had become a literature professor, a mother of two children and, as Guenther's once remarked, "mature but still young". This essay in memory of Guenther Roth is neither an obituary nor a scholarly appraisal of his sociological and historical work, but rather the attempt at recording the history of a friendship. Everyone who knew Guenther personally will always remember, and occasionally wonder at, the assured way he impersonated the values and issues that concerned him as a scholar. In writing down this testimony, I wish to remember and share how I grew to understand Guenther's personality and intellectual integrity.

Let me begin with a description of the last day of my visit to Guenther, on February 27 in 2019. We both knew, and Guenther said it upfront, that it would probably be the last time we saw each other. As I walked into the living room I saw two copies of his thick book, Max Webers deutsch-englische Familiengeschichte, 1800-1950, one wrapped, the other unwrapped, placed

\section{$(\mathrm{cc}) \mathrm{Br}$}

Direito autoral e licença de uso: Este artigo está licenciado sob uma Licença Creative Commons. Com essa licença você pode compartilhar, adaptar, para qualquer fim, desde que atribua a autoria da obra, forneça um link para a licença, e indicar se foram feitas alterações. 
on the couch in front of his chair. He asked me to sit down, picked up the unwrapped copy, sat on my side and read out loud the last paragraph of his work, a long citation of a letter Hannah Arendt wrote to her teacher, and lifelong friend, Karl Jaspers, in 1933. The subject of Arendt's commentary is an article published by Karl Jaspers in 1932 on Max Weber, under the title "Max Weber. Politiker. Philosoph. Deutsches Wesen im politischen Denken, Forschen und Philosophieren." In 1954, Ralph Mannheim would issue a "cleaned" (ROTH, 2001, p. 628) English translation of Jasper's article, in which the most embarrassing nationalistic statements of Weber, which Jasper's had avowedly incorporated in his encomium, were left out. The result was a historical falsification, a Geschichtsklitterung (ROTH, 2001, p. 628). "This was all the more regrettable", as Roth points out, "given the fact that the young Hannah Arendt had reacted to the text, by the time of its publication, with clear-sightedness." Still unaware of the coming catastrophe, she had told Jaspers:

Es handelt sich dabei nicht darum, das Sie in Max Weber den großen Deutschen, sondern dass Sie in ihm das ,deutsche Wesen' darstellen, und dass sie dies mit, Vernünftigkeit und Menschlichkeit aus dem Ursprung der Leidenschaft' identifizieren. Das bereitet mir die gleiche Schwierigkeit der Stellungnahme wie die zu dem eindrucksvollen Patriotismus Max Webers selbst. Sie werden verstehen, dass ich als Jüdin dazu weder Ja noch Nein sagen kann. [...] Für mich ist Deutschland die Muttersprache, die Philosophie und die Dichtung. Für all das kann und muss ich einstehen. Aber ich bin zur Distanz verpflichtet, ich kann weder dazu noch dagegen sein, wenn ich den großartigen Satz Max Webers lese, zur Wiederaufrichtung Deutschlands würde er sich auch mit dem leibhaftigen Teufel verbünden. Und in diesem Satz scheint mir das Entscheidende offenbar zu sein (ARENDT, 1985, p. 52).

It does not bother me that you portray Max Weber as the great German but, rather, that you find the "German essence" in him and identify that essence with rationality and humanity originating in passion." I have the same difficulty of commenting on that as I do on Max Weber's imposing patriotism itself. You will understand that I as a Jew can say neither yes nor no and that my agreement on this would be as inappropriate as an argument against it. [...] For me Germany means my mother tongue, philosophy and literature. I can and must stand by all that. But I am obliged to keep my distance, I can neither be for nor against when I read Max Weber's wonderful sentence where he says that to put Germany back on her feet he would form an alliance with the devil himself. And it is this sentence which seems to me to reveal the critical point here (ARENDT, 1992, p. 16)'.

I I have slightly revised the translation to make the phrasing correspond with that of the original. 
That Hannah Arendt's outspoken rejection of German nationalism should be the closing words of Roth's book is, of course, significant. The reasons for her disapproval resonate with the book's overarching argument. Had it been in accordance with the author's choosing, the book would have been titled "From Cosmopolitanism to Nationalism", a shorthand for the fateful transformation of Max Weber's Anglo-German family history. Besides marking her difference from both Weber's and Jasper's political positions, Arendt's statement reaches beyond the immediate context of the letter by foreshadowing the coming events. In Arendt's capacity to recognize the danger inherent in nationalism and name it as something that was "decisive" lies her clear-sightedness. Furthermore, she sees her reaction to Weber's patriotism and its consequences as an imperative, "ich bin zur Distanz verpflichtet"; his readiness to make a pact with the devil for the sake of Germany was decisive also in the sense that one had to respond to it by taking up a position. Arendt's willingness to speak out and take a position, which she pointedly underlines by her choice of words - Stellungnahme, Distanz, and das Entscheidende - struck me in hindsight as something relevant to understand Guenther's personality and attitudes. So I began to link Arendt's and Roth's biographies: their existence as emigrants from Nazi and post-war Germany, respectively; their pursuit of historical truth in understanding the rise of authoritarian and totalitarian regimes; their capacity to argue for and state their positions both in private and in public.

The ending of Roth's book embodies one of his main concerns: the clarification of the concrete individuals responsible for the publication history of a text, the actual reach of their decisions and, last but not least, the acknowledgment of women's distinct intellectual contribution. By reproducing Arendt's own words, Roth shows, in actu, as it were, Arendt's readiness for defying authority and comprehending what was at stake in the early 1930's. Arendt's exemplary Stellungnahme at a young age and throughout her life bear, I wish to say, on Roth's resolute decision to leave post-war Germany; his lifelong effort to understand modern society and political systems from a critical, historical perspective; his view that, because dictatorships and authoritarian regimes misrepresent and threaten the pursuit of historical truth, scholars should take upon themselves the 
responsibility to ensure the political conditions of their own existence. The direct citation from Arendt's letter attests, finally, his commitment to let others speak in their own voice. This commitment shaped Roth's sociability, and historical sensibility; it carried his joy in unearthing letters in family archives, and gratified his efforts to ensure the careful publication of his findings.

That Guenther chose to read that particular passage to me on the day of my last visit relates, as well, to my own trajectory and work. Guenther knew that, before I moved to NYC, I had translated the correspondence between Hannah Arendt and Karl Jaspers, and that the translation had never been printed. The publishers pushed the publication of the more fashionable correspondence between Arendt and Heidegger ahead and, in the process, lost the right to publish my translation. Back then, in the spring of 2019, I was particularly pleased, as I had told Guenther, that a small publishing house had acquired the rights of a text included in the correspondence, a speech Arendt made in honor of Jaspers after his death at the University of Basel. My translation of this beautiful speech had been finally published in a little volume together with an essay originally titled "Freedom to be free" (ARENDT, [1955, 1969] 2018).

Guenther's tacit acknowledgement of my experience as a translator on the day of my last visit circles back to the circumstances of the first day we met in the fall of 1996. I was then translating Reinhart Koselleck's Critique and Crisis into Portuguese and hoped to dissipate terminological doubts by consulting with the great Weber scholar and translator of Economy and Society. I sent him an email asking if he could see me during his office hours. He listened attentively to my questions, told me about the book's reception in the US (and gave me Xerox copies of the most relevant secondary literature). He did not hesitate to ask my opinion about the book's argument and to express his fierce skepticism about its historical validity. I immediately liked his outspokenness. Later in the fall, he called me to ask if I would like to sort out the German books which might interest me and which he would have to clean out of his office before retiring in the spring. When I arrived in his office, he set a condition maybe it was half-jokingly, but I took it to heart - that I did not take 
up another translation until I was done with the dissertation. I kept my promise. The first translation I did was in the short interlude after my dissertation defense and before the award of a postdoc fellowship.

As we shared the background which had allowed us to become translators, it gradually sealed our friendship. Some people knew, because of my language skills, that I had spent my childhood in Germany, but only a few, Guenther among them, knew that my parents had escaped persecution in the early 1970's by the Brazilian military dictatorship. Thanks to the efforts of the Ökumenisches Studienwerk in Bochum to rescue political refugees they could settle with their two children in Germany and pursue their graduate education as sociologists. Guenther was the first person who called my attention to the fact that my dissertation topic (the first reports from the New World which were printed in Germany) originated from my own biography, something I knew, but had never reflected upon. Moreover, in the middle of a conversation about the translation of sociological concepts, he asked why I had chosen the English, rather than the German Department, as home department. As a proof of the troublesome standards of the English Department he cited, among other things, a dissertation project on Émile Durkheim by a candidate who did not read in French nor cared about the reception history of his work. I explained that, when I applied, I was led to think that Comparative Literature was associated with English, that I did not know that I could have chosen any other department affiliated with Institute for Comparative Literature and Society. I also explained that I was taking a seminar in the German Department and that I enjoyed the intellectual atmosphere there, but that I would have to consider the better funding opportunities available in the English Department. Guenther's reaction was unwavering: He asked if I had come to Columbia for the money or for my education. I took the first steps to switch to the German Department on the next day and remained grateful for his straightforwardness not just then, but on many other crucial occasions.

Luckily, my first year in graduate school overlapped with Guenther's last year before retirement. It was also a blessing, I think, to the Sociology students who still had the chance to take his theory classes. Among them were my 
ex-husband, Carlos Costa Ribeiro and a close friend, Fernanda Wanderley, who never failed to speak enthusiastically about Guenther's unconventional and surprising classes. Being somewhat older than their cohort, having done empirical research, and written a Master's dissertation, they somehow could relate more easily to Guenther's intellectual standards than the average graduate student. Early in the semester they mistakenly took a reading for a written assignment and handed in a comprehensive review of a substantial part of the reading list. Guenther read, commented and corrected their work and, in the next seminar section, referred to them in front of other classmates as an example to be followed "you should all do like the Brazilian students." In private, he strongly advised them to take their theory exams earlier, and thereby be able to spend more time on their research projects. It was something of a challenge - let alone a reversal of expectations. They had to overcome their scarce experience in writing in English, and they had to quickly come to terms with North-American approaches to classical authors that were partly unknown to them. On the eve of the exam, Fernanda spoke with Roth over the phone. I think, she told me, he was trying to encourage me, but frankly, I did not understand his phrasing, something like it was not the time to "chicken" or to be "freaking" out. We both puzzled over and laughed about the meaning of "chicken" or "freaking" out and how little sense these words made in Portuguese. Guenther was happily reassured when the "Brazilian students" passed their exams. Years later, I learned reading his autobiography that, as a young German graduate student at Berkeley, with a reputation for knowing theory, he had failed his theory exam, which he decided to take early. The way he writes about his failure is telling: "When I tried to make the qualifying examinations after only six months, I was flunked and sent back to read the seventy-five books that everybody had to read on pain of failing. Having to study books with a variety of orientations that I had disdained or disregarded before broadened my horizon in a most salutary manner" (ROTH, 1990, p. 403).

Roth's retirement ceremony was held in the spring of 1997 in the large and bright room of Columbia's Faculty House. I still have vivid memories of that day. I remember that Guenther's wife, Caroline Walker Bynum, at that time professor of medieval history at Columbia, was worried that Antonia, her daughter, might not find the hidden entrance to the building. 
So Fernanda and I offered to wait outside for Antonia. Besides social scientists and some colleagues from other institutions, faculty from the German Department came, and a number of students I had never met before. A younger faculty member acknowledged what I already knew, that Guenther thought that aging faculty should know the right time to leave and open up room for the younger generation. A German faculty member greeted Guenther by calling him "Du Glücklicher," ("you lucky one"), adding that retirement finally allowed one to do his own work, a sentence I would recall when I got a permanent position. Guy Oakes gave a memorable speech, titled "Guenther Roth and Weber Studies in America," which was published in the fall of 1997. Beginning with spirited observations on Weber's Science as Vocation, Oakes approached Roth's contribution to Weber studies remarking that "To come to terms with Economy and Society as Guenther Roth has done, is not merely to translate a book of monumental proportions, but to follow Weber's path in charting this universe" and that in "elaborating and refining Weber's work" Roth "concentrated primarily in political sociology." I did not know and was struck to learn that Roth's authority in the field was also related to the "well over a hundred reviews" he had written and that he "practiced reviewing as a scholarly responsibility" (OAKES, 1997, p. 178). Oakes emphasized that in view of the widespread conception of reviewing as marketing, "the sort of criticism practiced by Guenther Roth - actually studying the book under review, locating a work in its disciplinary and historical context, and assessing its merits - appears as a somewhat quaint and increasingly marginal activity." Many of us in the audience took these words to heart and rushed to the library to learn the stakes of scholarly debate from Guenther's sharply written - some with unforgiving irony - reviews.

The next years Guenther was emeritus but not retired - he worked intensely, traveling to archives and doing research on a wealth of new sources to write his great book on the history of Max Weber's family, published in 2001. These were busy years for me as well, as I finished my dissertation, with two children, in-between two continents. We kept in regular contact throughout the years. When Guenther visited on Morningside Drive for the first time after my son's birth in 1998 he 
gave me a postcard of Cronus eating his children and warned "the clock is ticking." The postcard is either in a book, or among memorabilia, so I cannot recover the painting's reference, but remember feeling surprised at Guenther's memento as Joaquim was less than three months old. That year and afterwards we sometimes met on Riverside Park for a walk, in the afternoon, after pick-up time at daycare or summer-camp. Guenther seemed perfectly at ease, even familiar with our peripatetic arrangement. We spoke about the latest political news, everyday routine and writing hours, and I marveled when he told me how his eldest son stayed in the baby seat while he worked. On Joaquim's first birthday Guenther brought him from Germany a wonderful gift: a Speiseschieber (baby food pusher), made of stainless steel, an object that was already a counter-cultural rarity. He had to go on a real odyssey to find it and eventually ordered it directly from the manufacturer. The little anachronic, civilizational device became a much beloved and envied object in the family, and the German word part of daily parlance at home, to the point that my children's closest friends knew what it meant.

After settling back in Rio de Janeiro, I would always welcome an excuse to visit New York and every time I would meet Guenther for lunch in the neighborhood and, if time allowed, for a museum visit. He knew everything about the application process at Brazilian universities and listened patiently to my exasperated ethnographies of "concursos", the cumbersome written and oral exams candidates have to take. We talked about the efficacy of affirmative action, the expansion of higher education, university politics, and the outcome of elections. He was, I think approvingly, amused by my argument in defense of Brazilian mandatory voting as a Kantian antinomy of progress. He would compare citizenship rights in the US and Europe, and explain to me what a local referendum was all about. The challenges to reconcile motherhood and academic work were a persisting topic. He always knew exactly how old my children were, Joaquim and Clara, and wanted to hear how they were thriving. More often than not the first question he asked was about my mother, Glaucia Villas Bôas, whom he had met as a fellow sociologist, and editor of two articles he published in Brazil. Whenever I sent him my work, he read it promptly and with attention. Sometimes he could not relate to the literary- 
theoretical parts of it, but mostly enjoyed the historical arguments I made. Over the years Guenther shared with enthusiasm the accomplishments of his stepdaughter, Antonia Walker, as a triathlon athlete. He never failed to make detailed reports about Caroline's career, ongoing projects, and books in print. If he realized that I did not yet have a copy of her latest book, he would swing by at a local bookstore on the way home and get me one. Guenther was overjoyed when Caroline was elected 2012 to the Orden pour le mérite für Wissenschaften und Künste of the Federal Republic of Germany. I remember him proudly describing the occasion of two framed pictures of Caroline that stood one a book shelf in his office: one in which she holds the "Report of the Committee on the Status of Women in the Faculty of Arts and Science" at Harvard University, and another one in which she is wearing the medal of the "Orden pour le mérite".

Perhaps because I am an early modernist I read more Bynum's than Roth's work. Still, as I engaged their writings I often wondered about their intellectual ties and forms of collaboration. I found indication of their exchange not only in the several mutual dedications of their work to each other, but also in their approach to, and choice of, subject matters. Bynum's discussion of the Cistercian conception of 'community', her distinction between the "individual" and "self" in Jesus as Mother (1982), as well her reassessment of the typologies of Max Weber and Ernst Troeltsch, based on her work on the mysticism and asceticism of medieval women in Fragmentation and Redemption (2012), seemed to bear the imprint of a rich dialogue. Roth's efforts to recuperate and understand Marianne Weber's intellectual legacy ("Marinane Weber and Her Cicle", 1988), his steady interest in highlighting the work and action of women in history were certainly inspired by Bynum's work on women's spirituality and piety. Indeed, if we pay close attention to the phrasing of Guenther's dedication of Webers Familiengeschichte, we learn that his tribute to Caroline reaches beyond that: "Ich widme dieses Buch meiner Frau Caroline Walker Bynum, Dr. h. c. mult., Mediävistin an der Columbia University in the City of New York - Magistra verbo et exemplo. (ROTH, 2001, p. XX). The phrase tying biography and scholarship together is a tacit reference to Bynums's first book, Docere verbo et exemplo. An Aspect of Twelfth Century Spirituality (1979). 
In the long intervals I could not come to NYwe kept in touch over email. Guenther never failed to send his birthday greetings to me and my children ("mother's should also be congratulated", he once wrote) as well as a Merry Christmas message, in either German or English, the languages we used to communicate. In the last years he would also send me, as attachment, a Jahresbericht, which he circulated among friends and relatives before new year's eve. In January 2016 he wrote a short birthday report which is characteristic of his self-irony and capacity to blend matter-of-factness and historical sensibility. After writing that the visit of the mayor to German friends on the occasion of their golden wedding celebration demonstrated the persistence of an old German custom, he adds that for the first time, and to his utter surprise, he was sent an official birthday greeting from his Senator, Adriano Espaillat, the first Dominican-American elected to New York's state legislature. Guenther attributes Espaillat's birthday card to an aging German-American to the culturally diverse electorate the Senator needed to address. Reminded by his wife that on his $100^{\text {th }}$ birthday he would receive a greeting card from the President, he foresees the vanishing worth of fellow centenarians in 2031 and juxtaposes this prediction with an appreciation of Obama's dignity at making his last State of the Union Address.

Seine Hausmacht ist dominikanisch, aber er braucht eine Koalition. So werden die Geburtstagsgruesse auch auf Spanisch, Chinesisch, Japanisch, Russsisch, Polnisch und Hebraeisch gedruckt. Caroline erinnerte mich daran, dass wenn ich hundert Jahre alt werde, ich einen Gruss vom Praesidenten der USA bekommen werde, wer das auch im Jahre 2031 sein mag. Da es bis dahin sehr viel mehr Hundertjaehrige geben wird, wird der seinerzeitige Praesident mehr zu tun haben als Obama, der gerade seine letzte State of the Union Rede in wuerdiger Form vor dem Kongress gegeben hat (Birthday report, 2016),

His power base is Dominican, but he needs coalition. So birthday cards are printed in Spanish, Chinese, Japanese, Russian, Polish and Hebrew. Caroline reminded me that, when I turn one hundred years old, I will receive a birthday greeting from the president of the United States, whoever he might be in 2031 . Since until then there will be many more centenarians, the president at that time will have more to do that Obama, who just made with dignity his last State of the Union Address to the Congress. (The author's translation). 
As I reread our correspondence it becomes clear that Gunther was fully aware of the political situation: "Politically, the new year will be a nightmare. We tried hard, with financial commitment, to restore the Democratic majority in the Senate, but we lost. I'll attach a memo I wrote soon after the election to German friends and relatives. In the meantime the terrible consequences become clearer every day." (Email from 2 January 2017) The last time we met was two years after Trump's, two months after Bolsonaro's election. We talked about politics and what he described as a return in the present of the problems from the 1930s he believed had been overcome. He asked me how often my son living in Germany had to renew his visa and whether citizenship rights were a possibility at all. When I asked how he felt about his US citizenship he replied that he was still proud of his American passport.

Reflecting on his words over and over I decided to reread Guenther's autobiography, which I had read in 2014, at a time when the political horizon seemed to be more distant from the 1930's. First I reread the expanded German version, "Politische Generationserfahrung und politisches Interesse: Versuch über eine deutsch-amerikanische Laufbahn" (ROTH, 1987:246-282), then the English "Partisanship and Scholarship" (ROTH, 1990, p. 383-409): "I grew up in Nazi Germany in a hurry. War made me a political animal; liberation an intellectual; emigration a political sociologist”. (ROTH, 1990, p. 383) read the quick opening lines, absent from the German version. They offer a short cut to the most crucial formative events of an individual's vocation born out of political experience and insight. As the text unfolds, historical existential determination (Seinsverbundenheit) is relativized, "individuals react differently to the same events"(1990, p. 383). But upon acknowledging individual difference, the commonality of generational post-war experiences is reasserted: "Too young to actively rebuild German democracy and economy, we were the prime beneficiaries of the reconstruction" (1990, p. 383). Throughout the narrative Roth draws on notions, which applied heuristically allow him to contrast his generation with his schoolmates at the humanistic Gymnasium, his antifascist family background, or his sense of belonging to his generation "as an outsider, an observer, and an occasional participant" (1987, p. 383). 
In the German title, the term Versuch, meaning attempt or experiment, resonates with the author's objection to determinism, already suggested by the book's title Political domination and personal freedom (Politische Herrschaft und persönliche Freiheit), and made explicit in the section dedicated to Reinhard Bendix's non-deterministic conception of history, "which dwells on the relationship between freedom and constraint." ("die um das Verhältnis von Freiheit und Beschränkung kreist." (ROTH, 1987, p. 233). Like Bendix, his mentor, Roth was critical of both deterministic and idealistic historical interpretations. Removed from the retrospective determinism or historical inexorability, they both shared "[Weber's] conviction about the individual's capacity to make, the power of circumstances notwithstanding, moral decisions" ("der Überzeugung von der Fähigkeit des Individuums, moralische Entscheidungen trotz der Macht der Umstände zu treffen,” 1987, p. 234).

Guenther's reconstruction of the nexus between his life and his work, which he claims was "blurry" to him (ROTH, 1990, p. 384) entails an element of Bildung, of formative development and apprenticeship. If political perceptions, not the academic discipline per se, drew him to do social sciences, he underwent three distinct moments in his career path (Laufbahn). When he joined the Social Student Federation and became the youngest research assistant at the Institute of Social Research at Frankfurt we read: "In fact my historical, sociological, and political interests were all bound up with one another in a tangle of scholarship and partisanship." (1990, p. 396-7). When he finished his doctoral dissertation at Berkeley on The Social Democrats in Imperial Germany he had moved from political activism to the study of political reality, and displaced to a foreign country, eventually came to "accept the role of observer over that of actor."(1987, p. 403). The third and last moment, which occurred in the 1960's, Roth curiously phrases as "reawakening": "My political combativeness was reawakened by the challenge of a younger generation that knew nothing about war and fascism. My response took the form a partisan defense of scholarship." (1990, p. 405). By "partisan defense of scholarship" Guenther refers to his understanding that any defense of the university against the dangers of "radical politicization" rested on the separation of scholarship and partisanship (1987, p. 405). Unlike older refugee scholars, like Bendix or Adorno, who became the target of "anti-authoritarian" movements, Roth 
was still able at Berkeley to persuade militant students to enroll his courses on Weber's sociology of domination. By reading Politische Herrschaft und persönliche Freiheit I could learn how Roth applied Weber's sociology of domination to understand concrete constellations of political modernity and the contradictions of post-war world powers. Weber's concepts are not put in the service of a normative theory of modernity to identify transitional stages between tradition and modernity or between charisma and bureaucracy. Rather, Weber's distinctions are explored and tested broadly to understand new forms of political personalism in democracies or communist regimes, counter-cultural or revolutionary movements. Insofar as Roth's exercise sheds light on the coexistence of old and modern structures, he corroborates the lesson he draws from Weber's work: "By and large sociology remains to Weber an auxiliary discipline to history, Clio's maidservant" ("Die Soziologie bleibt für Weber weitgehend eine Hilfswissenschaft der Geschichte, Klios Dienstmagd”) (1987, p. 26-27).

Let me return to my last visit to Guenther. As I have said before, we did not go to the exhibition on the Hudson River at the New York Historical Society. But, on the second day we met, we saw the exhibition "Jewelry: The Body Transformed" at the Metropolitan Museum. Because of his limited mobility, Guenther used a walker. So we had to take a cab and get into the building through an entrance accessible to disabled visitors. As usual, he had seen the exhibition before and guided me through it, complementing and correcting available information, smiling at my naive questions. Although visibly worn, he insisted that we should have lunch in the museum's cafeteria. When we finished eating our sandwiches he suggested that I should spend the afternoon in the museum, and that he would find his way home by himself. Obviously I was going to escort him home, so we settled for a compromise: I asked him to show me an art work that was especially meaningful to him. He was silent for a long moment. Then we headed to the American Wing.

Guenther had chosen to show me "America Today," a mural painted in 1930-31 by Thomas Hart Benton, comprising ten canvas panels. ${ }^{2}$ The

2 Reproductions of the panels integrating the mural are available on the site of the "Heilbrun Timeline of Art History" at: https://www.metmuseum.org/toah/hd/bent/hd_bent.htm. 
panels convey Benton's view of modernization, differentiated according to regions, modes of production, and life styles. In depicting the progress of modern technology, Benton emphasizes the realities of manual and industrial labor. The coal, steel and urban construction industries are compared with the cotton industry of the "Deep South" and its reliance on African American Workers, or the farming and logging activities in the Midwest. Throughout the panels representing the country's production chains and labor division, racial tensions are pushed to the foreground. The last and smallest panel, titled Outreaching Hands, shows the aggravation of inequality caused by the Great Depression framing out one body part of the American 'body' politic: hands reaching for food are set in opposition to other hands holding money and against the façade of a prison in the background. Two panels titled City Activities with Dance Hall and City Activities with Subway elaborate on the liberating and conflictual sociability of urban life. Scenes of dancing to jazz music, and drinking (during Prohibition 1920-33), alternate with box matches, lovers kissing on a public square, passengers strap-hanging in the subway, or spectators in a movie theatre. At first, Guenther pointed out the main features of each one of the panels sitting on a bench. Unable to remember all the facts about the mural's commission he blamed the feebleness of his "old brain." Soon enough, before we could really notice, he was making observations moving around the room without the walker.

Today, I can hardly tell apart what Guenther taught me that day from what I read about Benton's mural afterwards. I know that the mural was commissioned by the director of the New School for Social Research in 1930 to decorate the boardroom of a new building opened in 1931. It remained in the New School for more than fifty years until it was acquired by an insurance company in 1982, and finally donated to the Metropolitan Museum in 2012. I know that when Guenther moved to the US in 1953 he worked at Ohio State University, and then spent the year 1954-55 at the New School. Did he ever enter the room where Benton's mural was? Did he hear about it from the emigré community he lived in? How did it match his own perceptions of American society? There are indeed many questions 
I did not have the time to ask him. But, as I seek answers to these, and many other questions, I can draw on my memories about Guenther, and embrace them with gratitude.

\section{References}

ARENDT, H. \& K. JASPERS. Briefwechel 1926-1969. 1 February 1933. Zurich: Piper, 1985, p. 52.

Correspondence 1926-1969. 1 February 1933. New York: Harcourt Brace \& Jovanovich, 1992, p. 16.

Homenagem a Karl Jaspers. Trad. Luciana Villas Bôas. In: DUARTE, P. (Org. e trad.). Liberdade para ser livre. Rio de Janeiro, Bazar do tempo, 2018.

BENTON, T.H. America Today. Available at: "Heilbrun Timeline of Art History" at: https://www. metmuseum.org/toah/hd/bent/hd_bent.htm. Accessed 25 May 2020.

BYNUM, C.W. Docere verbo et exemplo. An Aspect of Twelfth Century Spirituality, Harvard Theological Papers, Missoula: Scholar's Press, 1979.

Jesus as Mother. Studies in the Spirituality of the Late Middle Ages. Berkeley: University of California Press, 1982.

Fragmentation and Redemption. Essays of Gender and the Human Body in Medieval Religion. Cambridge MA and New York: MIT Press and Zone Books, 1992.

OAKES, G. Guenther Roth and Weber Studies in America. International Journal of Politics, Culture, and Society, v. 11, n. 1, p. 175-179, 1997.

ROTH, G. Politische Herrschaft und persönliche Freiheit. Heidelberger Max WeberVorlesungen. Frankfurt a. M.:Suhrkamp, 1987.

Marianne Weber and Her Circle. In: ZOHN, H. (org. e trad.). Marianne Weber, Max Weber. A Biography. New Brunswick: Transaction Books, 1988, p. xv-lxi.

Partisanship and Scholarship. In: BERGER, B. (org.) Authors of Their Own Lives. Berkeley: University of California Press, 1990, p. 383-409.

Max Webers deutsch-englische Familiengeschichte 1800-1950. Mit Briefen und Dokumenten. Tübingen: 2001. 